\title{
Ingenamine $\mathbf{G}$ and Cyclostellettamines $\mathbf{G}-\mathbf{I}, \mathrm{K}$, and $\mathbf{L}$ from the New Brazilian Species of Marine Sponge Pachychalina sp.
}

\author{
J aine H. H. L. de Oliveira, ${ }^{\dagger}$ Achim Grube, ${ }^{\ddagger}$ Matthias Köck, ${ }^{\ddagger}$ Roberto G. S. Berlinck, ${ }^{,+\dagger}$ Mario L. Macedo, ${ }^{\S}$ \\ Antonio G. Ferreira, ${ }^{\S}$ and Eduardo Hajdu ${ }^{\perp}$ \\ Instituto de Química de São Carlos, Universidade de São Paulo, CP 780, CEP 13560-970, São Carlos, SP, Brazil, \\ Alfred-Wegener-Institut für Polar- und Meeresforschung in der Helmholtz-Gemeinschaft, Am Handelshafen 12, \\ D-27570 Bremerhaven, Germany, Departamento de Química, Universidade F ederal de São Carlos, São Carlos, SP, Brazil, and \\ Museu Nacional, Universidade Federal do Rio de J aneiro, Quinta da Boa Vista, s/ n, 20940-040, Rio de J aneiro, RJ , Brazil
}

\section{Received April 12, 2004}

The chemical investigation of the cytotoxic and antituberculosis active $\mathrm{MeOH}$ crude extract of the marine sponge Pachychal ina sp. led to the isolation of six new nitrogenous metabolites, including ingenamine $\mathrm{G}$ (1), as well as a mixture of new cyclostellettamines $G, \mathrm{H}, \mathrm{I}, \mathrm{K}$, and $\mathrm{L}(\mathbf{1 0}-\mathbf{1 4})$ with the known cyclostellettamines A-F (4-9). Structural assignments of compound 1 were based on the analysis of MS and NMR data, while the structures of compounds 10-14 could be established by HPLC-MS/MS analysis. Ingenamine G displayed cytotoxic activity against HCT-8 (colon), B16 (leukemia), and MCF-7 (breast) cancer cell lines, antibacterial activity against Staphylococcus aureus (ATCC 25923), Escherichia coli (ATCC 25922), and four oxacilin-resistant S. aureus strains, and antimycobacterial activity against Mycobacterium tubercul osis H37Rv.

Since the isolation of halitoxins by Schmitz's group in 1978 from sponges of the genus Haliclona (currently Amphimedon), ${ }^{1}$ marine sponges in the order Haplosclerida have proven to be an exceptionally rich source of both alkylpyridine and alkylpiperidine alkaloids. Comprehensive reviews of this structural class of secondary metabolites have appeared in 1996, ${ }^{2}$ 1997, ${ }^{3}$ and $2000.4,5$ Not only are these alkaloids considered chemotaxonomic markers of Haplosclerid sponges, 2,3 but many of them present potent biological activities. Such is the case for the antitubercuIosis and antiviral manadomanzamines from Acanthostrongylophora sp., ${ }^{6}$ the cytotoxic and strongly antibiotic arenosclerins from Arenosclera brasiliensis, 7,8 the antimalarial manzamines, ${ }^{9}$ and for xestospongins $A, C$, and $D$, araguspongine $B$, and demethylxestospongin $B$, a group of macrocyclic bis-1-oxaquinolizidines isolated from Xestospongia sp., which are potent blockers of I $\mathrm{P}_{3}$-mediated $\mathrm{Ca}^{2+}$ release from endoplasmic reticulum vesicles of rabbit cerebellum. ${ }^{10}$

In our current program for the investigation of biologically active natural products from marine invertebrates, ${ }^{11}$ we have recently prioritized the chemical investigation of the crude $\mathrm{MeOH}$ extract of a new species of marine sponge, Pachychalina sp. (Pinheiro, Berlinck, Hajdu, 2004), which displayed potent cytotoxic activity against HCT-8 colon cancer cells and B16 murine melanoma cancer cells, as well as antituberculosis activity against Mycobacterium tuberculosis H37Rv. A preliminary TLC analysis of the Pachychalina sp. $\mathrm{MeOH}$ extract indicated the presence of a very complex mixture of alkaloids. Herein we report the results of our initial efforts in identifying these alkaloids, which include the isolation of one new ingenamine-related alkaloid and five new cyclostelletamine derivatives.

\section{Results and Discussion}

The crude $\mathrm{MeOH}$ extract of Pachychalina $\mathrm{sp}$. was subjected to a solvent-solvent partition with EtOAc and

\footnotetext{
* To whom correspondence should be addressed. Tel: +55-16-2739954.

Fax: +55-16-2739952. E-mail: rgsberlinck@iqsc.usp.br.

† Instituto de Química de São Carlos, Universidade de São Paulo.

₹ Alfred-Wegener-Institut für Polar- und Meeresforschung.

$\S$ Departamento de Química, Universidade Federal de São Carlos.

$\perp$ Museu Nacional, Universidade Federal do Rio de J aneiro.
}

with n-BuOH. After evaporation, the EtOAc extract was dissolved in 9:1 $\mathrm{MeOH}-\mathrm{H}_{2} \mathrm{O}$ and partitioned with hexane. The $90 \% \mathrm{MeOH}$ extract was evaporated, and the residue was dissolved in $\mathrm{CH}_{2} \mathrm{Cl}_{2}-0.5 \mathrm{~N} \mathrm{HCl}$. The organic fraction was collected (named $\mathrm{CH}_{2} \mathrm{Cl}_{2}$-acid). The aqueous fraction was basified ( $1 \mathrm{~N} \mathrm{NaOH}$ ) and partitioned with $\mathrm{CH}_{2} \mathrm{Cl}_{2}$. This organic fraction was designed $\mathrm{CH}_{2} \mathrm{Cl}_{2}$-basic.

Compound 1 was isolated from the $\mathrm{CH}_{2} \mathrm{Cl}_{2}$-basic extract by a series of chromatographic separations as an optically active glassy solid. Its FABMS showed a quasi molecular ion peak at $\mathrm{m} / \mathrm{z} 479$, on which a high-resolution measurement (measd 479.40007; calcd 479.40014) indicated the formula $\mathrm{C}_{32} \mathrm{H}_{51} \mathrm{~N}_{2} \mathrm{O}$ with nine degrees of unsaturation. Considering the four double bonds, indicated by analysis of the BBD and DEPT ${ }^{13} \mathrm{C}$ NMR spectra, the structure of 1 must have five rings. Additionally, analysis of the NMR data indicated the presence of three $\mathrm{sp}^{3}$ methines $(\delta 62.1$, 40.4, and 37.6), one $\mathrm{sp}^{3}\left(\delta\right.$ 44.6) and one $\mathrm{sp}^{2}(\delta$ 144.5) quaternary carbons, and five typical nitrogen-substituted methylene resonances ( $\delta 50.6,51.2,56.3,58.0,59.4)$, which suggested an ingenamine-type skeleton for $\mathbf{1}$. Dereplication within the MARINLIT was strongly indicative that $\mathbf{1}$ belongs to the ingenamine/ingamine, ${ }^{12}$ keramaphidin, ${ }^{13}$ and xestocyclamine ${ }^{14}$ dass of alkaloids. This hypothesis was further supported by comparison of the ${ }^{13} \mathrm{C}$ N MR data of $\mathbf{1}$ with those of ingenamine $F(2)^{12 c}$ and keramaphidin $B$ (3), ${ }^{12 c, 13}$ in particular chemical shifts of ${ }^{13} \mathrm{C}$ belonging to the tricyclic central core of these compounds (see Table 2 in the Supporting I nformation). Extensive analysis of NMR spectra including $\mathrm{HSQC}, \mathrm{HMBC},{ }^{1} \mathrm{H}-{ }^{1} \mathrm{H}$ COSY, HSQCTOCSY, and NOESY confirmed this assumption. In the COSY spectrum, we observed a vicinal ${ }^{1} \mathrm{H}-{ }^{1} \mathrm{H}$ correlation between $\mathrm{H}-4$ and $\mathrm{H}-5(\delta 2.40, \mathrm{~m})$, along with several ${ }^{1} \mathrm{H}-$ ${ }^{1} \mathrm{H}$ long-range correlations between the two hydrogens of the $\mathrm{CH}_{2}-9$ methylene $(\delta 1.79$ and 1.30$)$ and $\mathrm{H}-12 \mathrm{a}(\delta 3.35)$ and $\mathrm{H}-20 \mathrm{a}\left(\delta\right.$ 1.82); between the $\mathrm{CH}_{2}-10$ methylene signal at $\delta 3.15$ and $\mathrm{H}-12 \mathrm{a}$; and between both $\mathrm{CH}_{2}-12$ hydrogens ( $\delta 3.35$ and 2.24) and both $\mathrm{CH}_{2}-21$ hydrogens ( $\delta 3.15$ and 2.98). More informative were the long-range couplings detected in the HMBC spectra $(6,8,12$, and $15 \mathrm{~Hz})$ and in the HSQC-TOCSY spectrum, which showed ${ }^{1} \mathrm{H}-{ }^{13} \mathrm{C}$ cou- 
plings between $\mathrm{H}-2(\delta$ 2.95) and $\mathrm{C}-4(\delta$ 124.4); between $\mathrm{H}-4$ $(\delta$ 6.09) and C-2 ( $\delta$ 62.1), C-5 ( $\delta$ 37.6), C-33 ( $\delta$ 35.1), and C-34 ( $\delta$ 37.9); between $\mathrm{H}-5(\delta 2.40)$ and $\mathrm{C}-7(\delta$ 44.6) and C-12 ( $\delta$ 51.2); between $\mathrm{H}-6 \mathrm{a}(\delta$ 3.10) and C-4 and C-5; between both $\mathrm{CH}_{2}-6$ hydrogens and $\mathrm{C}-9(\delta 24.9)$; between H9a $(\delta 1.79)$ and C-7, C-10 ( $\delta$ 50.6); between H9b $(\delta 1.30)$ and $\mathrm{C}-8(\delta 40.4)$ and $\mathrm{C}-12$; between both $\mathrm{CH}_{2}-10$ hydrogens and $\mathrm{C}-8$; between $\mathrm{CH}_{2}-12$ hydrogens and $\mathrm{C}-7, \mathrm{C}-8, \mathrm{C}-9$, and $\mathrm{C}-10$; between $\mathrm{H}-21 \mathrm{~b}$ and $\mathrm{C}-12$; and finally between $\mathrm{H}-34$ and C-3 ( $\delta$ 144.5). These data enabled us to define the "cage-like" central core of $\mathbf{1}$ as identical to that of $\mathbf{2}$ and $\mathbf{3}$, including the relative stereochemistry, since the "central core" structure substituted by the two $\mathrm{N}$-alkyl bridges supports only one relative stereochemistry. Therefore, structural differences must be present in the two N-alkyl bridges of $\mathbf{1}$. Careful analysis of the NMR data indicated that the $\mathrm{N}$-alkyl bridge connecting N-1 to C-7 consisted of eight carbons, in agreement with the structures of ingenamines $A-D$, ingamines, ${ }^{12}$ keramaphidin $B, 13$ and xestocyclamine $A .{ }^{14}$ In the case of these previously reported compounds, this chain contained either one double bond at $\mathrm{C}-16$ or at $\mathrm{C}-17$ or three nonconjugated insaturations at C-15, C-18, and C-21 within the structures of ingenamines $\mathrm{E}$ and $\mathrm{F} .{ }^{12 c} \mathrm{H}$ owever, compound $\mathbf{3}$ showed two conjugated double bonds at C-15 and C-17, with a carbinol group at C-19. Analysis of the NMR data clearly indicated that the methylene $\mathrm{CH}_{2}-13$ ( $\delta$ 58.0) was vicinally coupled to the methylene $\mathrm{CH}_{2}-14$ ( $\delta$ 26.5), which was in turn at the allylic position to $\mathrm{CH}-15$ ( $\delta$ 132.6). The conjugated system was clearly observed through ${ }^{1} \mathrm{H}-{ }^{1} \mathrm{H}$ COSY and long-range $\mathrm{HMBC}$ and $\mathrm{HSQC}-\mathrm{TOCSY}$ couplings from $\mathrm{CH}$ 15 to $\mathrm{CH}-18(\delta 134.5)$ through $\mathrm{CH}-16(\delta 126.7)$ and $\mathrm{CH}-17$ ( $\delta$ 125.6). The $Z, Z$ stereochemistry was assigned to the C-15, C-17 unsaturated system on the basis of the coupling constants measured between $\mathrm{H}-15$ and $\mathrm{H}-16(\mathrm{~J}=9.5 \mathrm{~Hz})$ and between $\mathrm{H}-17$ and $\mathrm{H}-18(\mathrm{~J}=9.0 \mathrm{~Hz})$, as well as on the C-14 ( $\delta$ 26.5) and C-19 ( $\delta$ 67.3) high-field chemical shifts. The carbinol hydrogen methine $\mathrm{CHOH}-19(\delta$ 4.78) showed ${ }^{1} \mathrm{H}-{ }^{1} \mathrm{H}$ couplings with both $\mathrm{CH}-18(\delta$ 5.37) and $\mathrm{CH}_{2}-20\left(\delta 1.82\right.$ and 1.46 ), as well as ${ }^{1} \mathrm{H}-{ }^{13} \mathrm{C}$ long-range correlations with carbons $\mathrm{C}-16$ and $\mathrm{C}-17$. Finally, the methylene $\mathrm{CH}_{2}-20$ showed key ${ }^{1} \mathrm{H}-{ }^{1} \mathrm{H}$ and ${ }^{1} \mathrm{H}-{ }^{13} \mathrm{C}$ correlations with $\mathrm{CH}_{2}-19, \mathrm{C}-7$, and $\mathrm{CH}_{2}-9$. The remaining $\mathrm{N}$-alkyl bridge consisted of 14 carbons, two of which participate in a double bond. The position of the unsaturation was unambiguously established by analysis of the ${ }^{1} \mathrm{H}-{ }^{1} \mathrm{H}$ COSY spectrum, which showed a long-range ${ }^{1} \mathrm{H}-{ }^{1} \mathrm{H}$ coupling between $\mathrm{CH}_{2}-12$ and $\mathrm{CH}_{2}-21$, as well as vicinal ${ }^{1} \mathrm{H}-{ }^{1} \mathrm{H}$ couplings between $\mathrm{CH}_{2}-21$ and $\mathrm{CH}_{2}-22$, between $\mathrm{CH}_{2}-22$ and $\mathrm{CH}-23$, and finally between $\mathrm{CH}-23$ and $\mathrm{CH}-24$. The position of this double bond was also confirmed by analysis of the HMBC and HSQC-TOCSY spectra, which displayed long-range couplings between C-12 and the hydrogens of $\mathrm{CH}_{2}-21$, between $\mathrm{C}-21$ and the hydrogens of $\mathrm{CH}_{2}-22$, $\mathrm{CH}-23$, and $\mathrm{CH}-24$, between $\mathrm{C}-22$ and $\mathrm{CH}_{2}-21, \mathrm{CH}-23$, and $\mathrm{CH}-24$, between $\mathrm{C}-23$ and $\mathrm{CH}_{2}-22$ and $\mathrm{CH}_{2}-25$, and finally between $\mathrm{C}-24$ and $\mathrm{CH}_{2}-22$ and $\mathrm{CH}_{2}-25$. The $\mathrm{Z}$ stereochemistry was assigned to this double bond on the basis of the $\mathrm{H}-23 / \mathrm{H}-24$ coupling constant $(\mathrm{J}=10.3 \mathrm{~Hz})$ and the ${ }^{13} \mathrm{C}$ shielded chemical shifts of both $\mathrm{CH}_{2}-22$ ( $\left.\delta 22.5\right)$ and $\mathrm{CH}_{2}$ 25 ( $\delta$ 27.5). The ${ }^{1} \mathrm{H}$ and ${ }^{13} \mathrm{C}$ assignments of the remaining methylene chain were largely based on a detailed scrutiny of ${ }^{1} \mathrm{H}-{ }^{13} \mathrm{C}$ long-range couplings observed in $\mathrm{HMBC}$ and HSQC-TOCSY spectra. Both carbons C-33 and C-34 were shown to be long-range coupled to $\mathrm{H}-4$, establishing the attachment point of the second $\mathrm{N}$-alkyl chain to the $\mathrm{C}-3 /$
C-4 double bond. We proposed the name ingenamine G for compound $\mathbf{1}$.

Although the absolute stereochemistry of ingenamine G (1) herein isolated from Pachychalina sp. was not established, the similarity of both the specific rotation and NMR data observed for the ${ }^{1 \mathrm{H}}$ and ${ }^{13} \mathrm{C}$ at the central tricyclic core strongly suggests that it has the same absolute stereochemistry as ingenamine $F(\mathbf{2})$. We have not attempted to establish the absolute stereochemistry of $\mathbf{1}$, due to previous negative results on derivatizing with MTPA a similar conjugated allylic alcohol function in the arenosclerins. $^{7}$ Ingenamine $G$ (1) displayed cytotoxic activity against HCT-8 (colon), B16 (leukemia), and MCF-7 (breast) cancer cell lines at the level of $8.6,9.8$, and $11.3 \mu \mathrm{g} / \mathrm{mL}$, respectively, and antibacterial activity against Staphylococcus aureus (ATCC 25923) at $105 \mu \mathrm{g} / \mathrm{mL}$, Escherichia col $\mathrm{i}$ (ATCC 25922) at $75 \mu \mathrm{g} / \mathrm{mL}$, and four oxacilin-resistant S. aureus strains, two of which at concentrations between 10 and $50 \mu \mathrm{g} / \mathrm{mL}$, as well as antimycobacterial activity against Mycobacterium tubercul osis H37Rv at $8 \mu \mathrm{g} / \mathrm{mL}$.

Chromatographic separation of the n-BuOH crude extract (see Experimental Section) led to the isolation of two fractions containing 3-alkyl pyridinium alkaloids. ${ }^{1} \mathrm{H}$ NMR analysis of these fractions showed the very characteristic pattern observed for these compounds, which includes four aromatic hydrogen signals at $\delta 9.17(\mathrm{~s}, \mathrm{H}-2), 9.05(\mathrm{~d}, 7.1$ $\mathrm{Hz}, \mathrm{H}-6), 8.45$ (d, J = $7.1 \mathrm{~Hz}, \mathrm{H}-4)$, and $8.09(\mathrm{t}, \mathrm{J}=7.1 \mathrm{~Hz}$, $\mathrm{H}-5)$ as well as aliphatic hydrogen signals at $\delta 4.63(\mathrm{t}, \mathrm{J}=$ $6.7 \mathrm{~Hz}, \mathrm{CH}_{2}-7$ ), $1.89\left(\mathrm{~m}, \mathrm{CH}_{2}-8\right), 2.80$ (t, $6.7 \mathrm{~Hz}, \mathrm{CH}_{2}-9$ ), and $1.63\left(\mathrm{~m}, \mathrm{CH}_{2}-10\right)$ and a broad singlet between $\delta 1.14$ and 1.21 (methylene chain). ${ }^{15,16}$ Typical ${ }^{13} \mathrm{C}$ resonances of 3-alkylpyridine compounds were also observed in the HSQC spectrum. Although a preparative HPLC purification of these fractions lead to a single HPLC peak, further HPLC-MS/MS (ESI-TOF, API-CID) analyses of these fractions revealed the presence of an alkaloid mixture of the known cyclostellettamines A-F (4-9), together with the new cyclostellettamines G (10), H (11), I (12), K (13), and $L$ (14). The known cyclostellettamines $A-F$ (4-9) consist
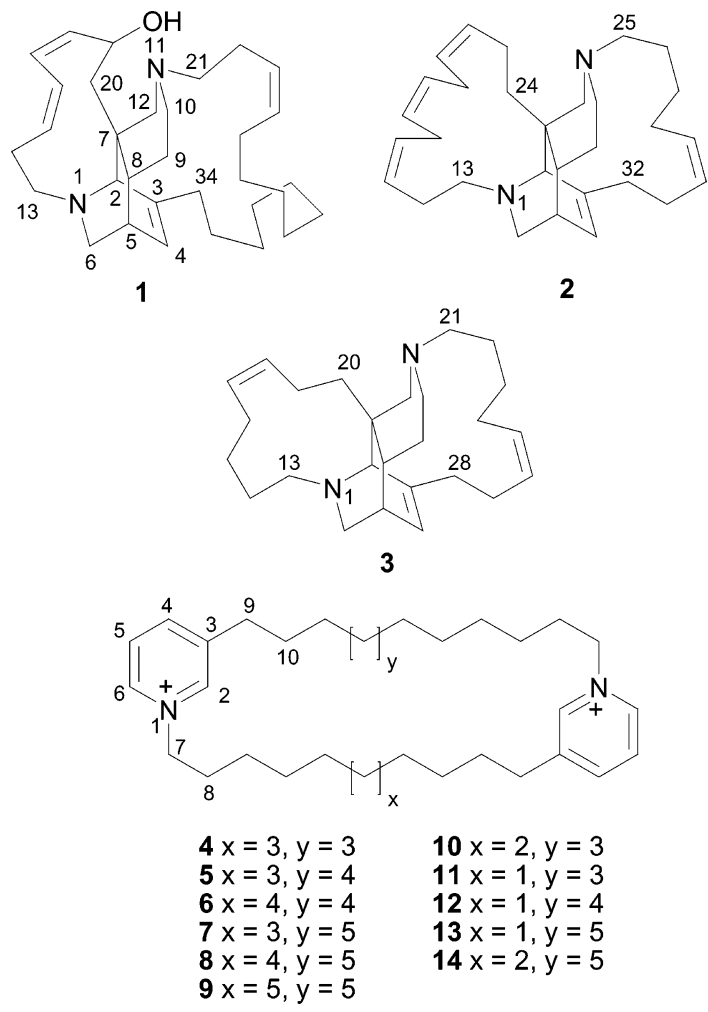


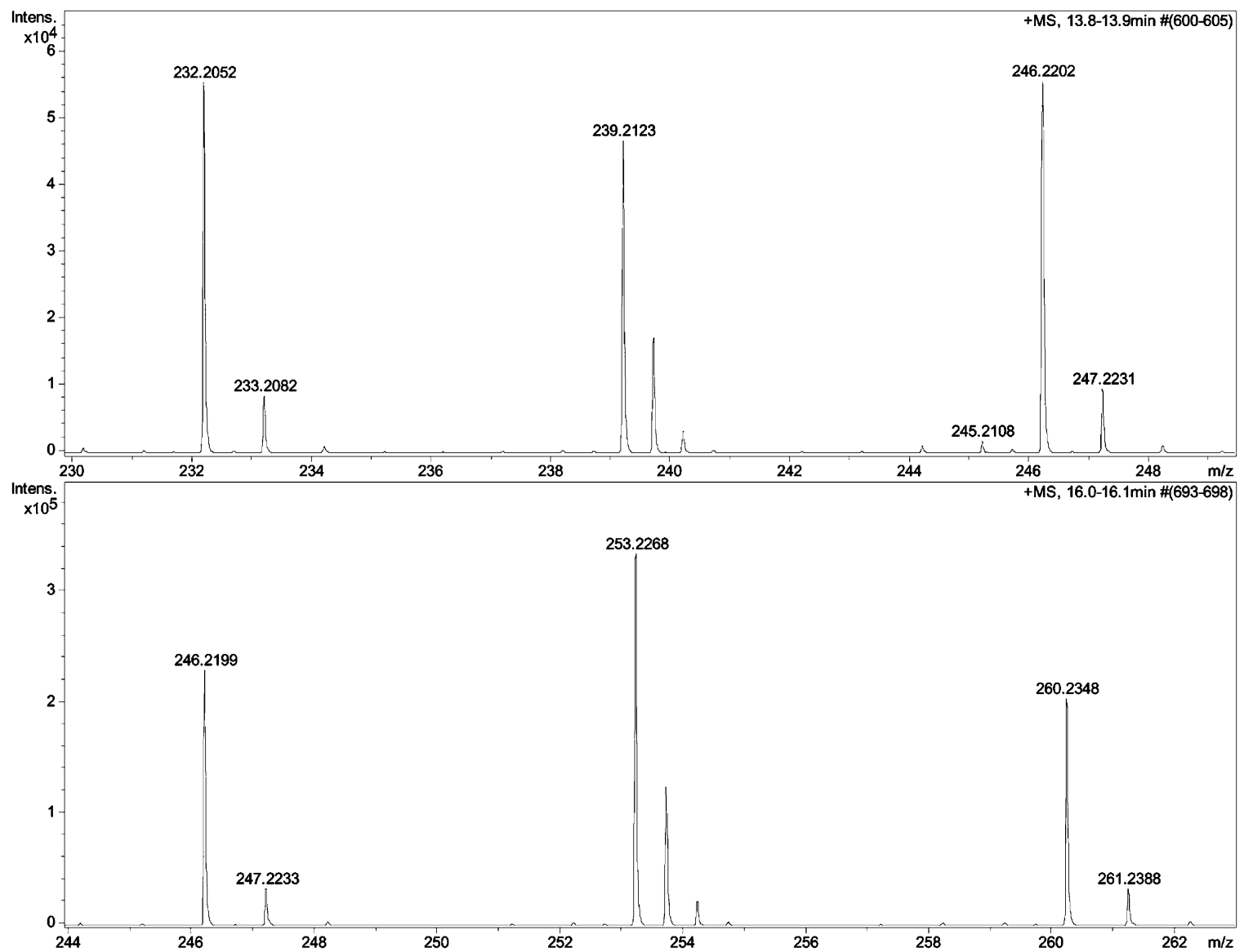

Figure 1. ESI-API-CID-mass spectrum of cyclostellettamine H (11, top) and cyclostellettamine B (5, bottom). The peak at $\mathrm{m} / \mathrm{z} 239$ is the doubly charged intact molecule ion $\mathrm{M}^{2+}$, which is proven by the mass difference of isotope peaks of one-half mass units. The other singly charged peaks at $\mathrm{m} / \mathrm{z} 232$ and $\mathrm{m} / \mathrm{z} 246$ are the main fragments of cyclostellettamine $H$ (11).

of alkyl chains with 12-14 carbon atoms each $\left(\mathrm{C}_{\mathrm{x}}\right.$ or $\left.\mathrm{C}_{\mathrm{y}}\right)$; the sum of both alkyl chains is therefore $24-28\left(\sum\left[C_{x}+\right.\right.$ $\left.\mathrm{C}_{\mathrm{y}}\right]$ ). The HPLC-MS/MS analysis showed five new cyclostellettamines with $\Sigma\left[C_{x}+C_{y}\right]=22,23$ (two different ones), 24 , and 25. Dimeric pyridinium compounds undergo a mass spectral cleavage that leads to a ring opening (Hofmann fragmentation). Therefore, usually the singly charged molecular ion $[\mathrm{M}-\mathrm{H}]^{+}$is observed at one mass unit less than its actual molecular weight. In our investigations only the doubly charged molecular ion $\mathrm{M}^{2+}$ was detected. This information together with the NMR chemical shifts proves unambigi ously the cycl ostel lettamine core. The distribution of the carbon atoms between the two alkyl chains $\left(\mathrm{C}_{\mathrm{x}}+\right.$ $\mathrm{C}_{\mathrm{y}}$ ) required information about the MS fragments (HR-MS/ MS analysis). Under API-CID conditions the two singly charged main fragments (probably due to two Hofmann fragmentations that split the molecules into halves) could be observed and used for the differentiation of the previously known cyclostellettamines (see Figure 1). The main fragments were identified on the basis of their intensity in the MS/MS spectrum (under API-CID conditions). Therefore, the new cyclostellettamines with $\Sigma\left[C_{x}+C_{y}\right]=$ 22 and 23 were identified as cyclostellettamines $G(\mathbf{1 0}, 11$ $+12),{ }^{17} \mathrm{H}(\mathbf{1 1}, 10+12)$, and I $(\mathbf{1 2}, 10+13)$. The sum $\Sigma\left[C_{x}\right.$ $\left.+\mathrm{C}_{\mathrm{y}}\right]=24$ and 25 was already known for cyclostellettamines A (4) and B (5). However, the information from the two main fragments indicated the occurrence of two further new derivatives, cyclostellettamines $\mathrm{K}(\mathbf{1 3}, 10+$ 14) and $L(14,11+14)$. We suggest that the name cyclostelletamine J should be given to the $11+13$ analogue, which has not been isolated yet.
Up to the present, the marine sponge Pachychalina sp. contain an interesting secondary metabolism profile. Although alkylpyridinium and alkylpiperidine alkaloids are commonly found within sponges of the order Haplosclerida, they are rarely found simultaneously. To the best of our knowledge, only the Mediterranean marine sponge Reniera sarai possesses halitoxins ${ }^{18}$ and alkylpiperidine alkaloids (sarains and isosarains). ${ }^{19}$ However, since bis-alkylpyridine alkaloids are currently considered to be the biogenetic precursors of their respective alkylpiperidine counterparts, as originally suggested by Cimino ${ }^{19 b}$ as well as by Baldwin and Whitehead, ${ }^{20}$ it is not surprising to have isolated both alkaloid classes within a single species of marine sponge. It is possible that the co-occurrence of both alkylpyridines and alkylpiperidines within sponges of the order Haplosclerida is more common than it has been reported. However, since alkylpyridine alkaloids are considered as nuisance compounds that interfere in various bi oassays, ${ }^{11,21}$ they are not usually investigated. We are currently identifying minor alkaloids of the marine sponge Pachychalina sp.

\section{Experimental Section}

General Experimental Procedures. Optical rotations were measured on a Perkin-EImer 241 MC polarimeter at 29 ${ }^{\circ} \mathrm{C}$. IR spectra (film on Si plate) were recorded on a FT-IR Bomem MB102 infrared spectrometer. The N MR spectra were recorded either on a Bruker ARX400 9.4 T instrument, operating at $400.35 \mathrm{MHz}$ for ${ }^{1} \mathrm{H}$ and $100.10 \mathrm{MHz}$ for ${ }^{13} \mathrm{C}$ channels, respectively, or on a Bruker DRX500 11.7 T, operating at $500.13 \mathrm{MHz}$ for ${ }^{1} \mathrm{H}$ and $125.76 \mathrm{MHz}$ for ${ }^{13} \mathrm{C}$, respectively. All NMR spectra were obtained at $25^{\circ} \mathrm{C}$ using TMS as internal 
Table 1. ${ }^{1} \mathrm{H},{ }^{13} \mathrm{C}$, COSY, HSQC-TOCSY, and HMBC NMR Data Recorded in $\mathrm{MeOH}-\mathrm{d}_{4}$ for Ingenamine G (1)

\begin{tabular}{|c|c|c|c|c|c|}
\hline position & $\delta^{13} \mathrm{C}^{\mathrm{a}}$ & $\delta^{1} \mathrm{H}$ (mult, J in $\mathrm{Hz}$ ) & COSYc & HSQC-TOCSYa,c & $\mathrm{HMBC}^{\mathrm{b}, \mathrm{c}}$ \\
\hline $\mathrm{CH}-2$ & 62.1 & 2.95 & & $\mathrm{H} 17$ & $\mathrm{H} 4$ \\
\hline$C-3$ & 144.5 & & & & H33ab, H34 \\
\hline $\mathrm{CH}-4$ & 124.4 & $6.09(\mathrm{~m})$ & H5 & $\mathrm{H} 2, \mathrm{H} 5$ & $\mathrm{H} 6 \mathrm{~b}$ \\
\hline $\mathrm{CH}-5$ & 37.6 & $2.40(\mathrm{~m})$ & $\mathrm{H} 4$ & $\mathrm{H} 6 \mathrm{~b}$ & $\mathrm{H} 4$ \\
\hline $\mathrm{CH}_{2}-6$ & 56.3 & $3.10(\mathrm{~m}) ; 1.96(\mathrm{~m})$ & & & \\
\hline C-7 & 44.6 & & & & H5, H9a, H12ab, H20 \\
\hline $\mathrm{CH}-8$ & 40.4 & $1.28(\mathrm{~m})$ & & $\mathrm{H} 9 \mathrm{~b}, \mathrm{H} 10$ & $\mathrm{H} 10, \mathrm{H} 12$ \\
\hline $\mathrm{CH}_{2}-9$ & 24.9 & $1.79(\mathrm{~m}) ; 1.30(\mathrm{~m})$ & $\mathrm{H} 12 \mathrm{a}, \mathrm{H} 2 \mathrm{O}$ & $\mathrm{H} 6, \mathrm{H} 12 \mathrm{a}$ & $\mathrm{H} 12, \mathrm{H} 20 \mathrm{~b}$ \\
\hline $\mathrm{CH}_{2}-10$ & 50.6 & $3.15(\mathrm{~m})$ & $\mathrm{H} 12 \mathrm{a}$ & H9a, H12a & $\mathrm{H} 12 \mathrm{a}$ \\
\hline $\mathrm{CH}_{2}-12$ & 51.2 & $3.35(\mathrm{~m}) ; 2.24(\mathrm{~m})$ & $\mathrm{H} 21 \mathrm{ab}$ & & $\mathrm{H} 5, \mathrm{H} 9 \mathrm{~b}, \mathrm{H} 2 \mathrm{lb}$ \\
\hline $\mathrm{CH}_{2}-13$ & 58.0 & $2.72(\mathrm{~m}) ; 2.33(\mathrm{~m})$ & & H14a, H15 & \\
\hline $\mathrm{CH}_{2}-14$ & 26.5 & $2.47(\mathrm{~m}) ; 2.07(\mathrm{~m})$ & H15 & $\mathrm{H} 13 \mathrm{a}$ & H16 \\
\hline $\mathrm{CH}-15$ & 132.6 & $5.64(\mathrm{~m}, 9.5,5.4)$ & H16 & & $\mathrm{H} 17$ \\
\hline $\mathrm{CH}-16$ & 126.7 & $6.37(q, 10.6)$ & H15 & H15, H17, H 19 & $\mathrm{H} 17, \mathrm{H} 18$ \\
\hline $\mathrm{CH}-17$ & 125.6 & $6.33(q, 10.6)$ & & $\mathrm{H} 18$ & $\mathrm{H} 15, \mathrm{H} 19$ \\
\hline $\mathrm{CH}-18$ & 134.5 & $5.37(\mathrm{~m}, 9.0,5.6)$ & $\mathrm{H} 17$ & $\mathrm{H} 20 \mathrm{~b}$ & $\mathrm{H} 15, \mathrm{H} 16, \mathrm{H} 20 \mathrm{a}$ \\
\hline $\mathrm{CH}-19$ & 67.3 & 4.78 (ddd, 3.9, 5.5, 9.7) & $\mathrm{H} 18, \mathrm{H} 20 \mathrm{a}$ & $\mathrm{H} 17$ & H16, H17 \\
\hline $\mathrm{CH}_{2}-20$ & 36.4 & $1.82(\mathrm{~m}) ; 1.46(\mathrm{~m})$ & H9, H19 & $\mathrm{H} 20 \mathrm{a}$ & $\mathrm{H} 19$ \\
\hline $\mathrm{CH}_{2}-21$ & 59.4 & $3.15(\mathrm{~m}, 4.3,8.1) ; 2.98(\mathrm{~m}, 4.3,8.3)$ & $\mathrm{H} 12 \mathrm{ab}$ & $\mathrm{H} 22 \mathrm{ab}, \mathrm{H} 23, \mathrm{H} 24$ & $\mathrm{H} 22 \mathrm{ab}, \mathrm{H} 23$ \\
\hline $\mathrm{CH}_{2}-22$ & 22.5 & $2.65(\mathrm{~m}) ; 2.27(\mathrm{~m})$ & H21ab, H23, H24 & H2lab, H22ab, H23 & H2lab, H23, H24 \\
\hline $\mathrm{CH}-23$ & 124.4 & $5.33(\mathrm{~m})$ & $\mathrm{H} 24$ & & H22ab, H 25ab \\
\hline $\mathrm{CH}-24$ & 134.5 & $5.72(\mathrm{dd}, 8.2,10.3)$ & $\mathrm{H} 25 \mathrm{a}$ & & $\mathrm{H} 22 \mathrm{ab}, \mathrm{H} 25 \mathrm{ab}$ \\
\hline $\mathrm{CH}_{2}-25$ & 27.5 & $2.24(\mathrm{~m}) ; 1.96(\mathrm{~m})$ & $\mathrm{H} 24$ & $\mathrm{H} 23, \mathrm{H} 24$ & $\mathrm{H} 21 \mathrm{~b}, \mathrm{H} 23, \mathrm{H} 24, \mathrm{H} 26$ \\
\hline $\mathrm{CH}_{2}-26$ & 28.9 & $1.40(\mathrm{~m})$ & $\mathrm{H} 25 \mathrm{~b}$ & & $\mathrm{H} 25 \mathrm{~b}, \mathrm{H} 9$ \\
\hline $\mathrm{CH}_{2}-27$ & $28.2^{d}$ & 1.24 (m) & & & \\
\hline $\mathrm{CH}_{2}-28$ & $27.9^{d}$ & $1.24(\mathrm{~m})$ & & $\mathrm{H} 29$ & \\
\hline $\mathrm{CH}_{2}-29$ & 26.2 & $1.02(\mathrm{~m})$ & H30 & $\mathrm{H} 26$ & H33b \\
\hline $\mathrm{CH}_{2}-30$ & $27.7^{d}$ & $1.28(\mathrm{~m})$ & & $\mathrm{H} 29$ & H30, H33ab \\
\hline $\mathrm{CH}_{2}-31$ & 27.5 & 1.44(m) & H33a & H30, H32, H33а & H32, H33b, H34b \\
\hline $\mathrm{CH}_{2}-32$ & 25.2 & $1.59(\mathrm{~m})$ & H33ab & H30, H31, H33а & H31, H33ab \\
\hline $\mathrm{CH}_{2}-33$ & 35.1 & $2.15(\mathrm{~m}) ; 2.05(\mathrm{~m})$ & & H31, H32 & H4, H32 \\
\hline $\mathrm{CH}_{2}-34$ & 37.9 & $2.05(\mathrm{~m}) ; 1.36(\mathrm{~m})$ & & $\mathrm{H} 4, \mathrm{H} 29, \mathrm{H} 30$ & H3O \\
\hline
\end{tabular}

a Assignments by inverse detection at $400 \mathrm{MHz}$ (HSQC). bl nverse detection at $400 \mathrm{MHz}$, for ${ }^{\mathrm{n}}{ }^{{ }^{13} \mathrm{C}-{ }^{1} \mathrm{H}}=8.3$. ${ }^{\mathrm{c} a}$ and $\mathrm{b}$ denote downfield and upfield resonances respectively of a geminal pair. ${ }^{d}$ Assignments may be reversed.

reference. Low-resolution mass spectra were recorded on a VG7070 mass spectrometer operating at a nominal accelerating vol tage of $70 \mathrm{eV}$. High-resolution mass spectra were recorded at a nominal resolution of 5000 or 10000 as appropriate. All spectra were obtained using $\mathrm{EI}, \mathrm{FAB}$, or $\mathrm{Cl}$ ionization techniques using perfluorokerosene, 3-nitrobenzyl al cohol, or poly(ethylene glycol) as the internal standard. LOBAR Lichroprep (Merck) separations were performed with size B $(310 \times 25 \mathrm{~mm})$ columns. Solvents used for extraction and flash chromatography were glass distilled prior to use. HPLC-grade solvents were utilized without further purification in LOBAR and HPLC separations. TLC analyses were performed with plasticbacked Si gel TLC sheets, eluting with different mixtures of $\mathrm{MeOH}$ in $\mathrm{CH}_{2} \mathrm{Cl}_{2}$. Plates were visualized by spraying with Dragendorff reagent. HPLC separations were performed either with a Waters quaternary pump 600, double beam UV detector 2487, and data module 746 or with a Waters autosampler 717, Waters 600 pump, and Waters 2996 photodi ode array detector monitored by Waters Millenium 32. For HPLC-MS/MS (APICID) analysis, fractions were dissolved in 2-propanol. The samples were injected into a HPLC System 1100 Series (Agilent) equipped with a photodiode array detector (Agilent) and a microTOF LC mass spectrometer (Bruker Daltonik). The detection with the DAD was performed at a wavelength of 260 $\mathrm{nm}$. Mass spectra were acquired with an ESI source (Bruker Daltonik). The following ESI inlet conditions were applied: dry gas temperature $180{ }^{\circ} \mathrm{C}$; dry gas flow $10 \mathrm{~L} / \mathrm{min}$; nebulizer pressure 1.5 bar; capillary vol tage $4500 \mathrm{~V}$. F or fragmentation the voltage of the Capillary Exit was set to $150 \%$ of the normal vol tage and the voltage of Skimmer 1 was set to $133 \%$ of the normal voltage.

Animal Material. The sponge Pachychalina sp. was collected in IIha do Pai (F ather's I sland), Niterói, Rio de J aneiro $\left(22^{\circ} 59.205^{\prime} \mathrm{S}-43^{\circ} 05.252^{\prime} \mathrm{W}\right)$, on May 9,2000 , at $10-15 \mathrm{~m}$ depth, and immediately immersed in $\mathrm{EtOH}$. The whole material was shipped to the Instituto de Química de São Carlos,
Universidade de São Paulo. Voucher specimens are deposited at the Museu Nacional (MNRJ 3098 and 3099).

Extraction and Isolation. The sponge $(2.0 \mathrm{~kg})$ was separated from the EtOH extract, blended in $\mathrm{MeOH}$, and left overnight. After filtration of the $\mathrm{MeOH}$ extract, the solid material was reextracted with $\mathrm{MeOH}$. Both $\mathrm{EtOH}$ and $\mathrm{MeOH}$ extracts were pooled and evaporated until $500 \mathrm{~mL}$ of an aqueous suspension was obtained. The $\mathrm{H}_{2} \mathrm{O}$ phase was partitioned with EtOAc. Then $25 \% \mathrm{NH}_{4} \mathrm{OH}$ was added to the $\mathrm{H}_{2} \mathrm{O}$ phase until $\mathrm{pH} \sim 10$, and the alkaline phase was partitioned with $\mathrm{n}-\mathrm{BuOH}$ to yield $5.1 \mathrm{~g}$ of a brown gum after evaporation.

The EtOAc extract was evaporated, dissolved in 9:1 $\mathrm{MeOH}-$ $\mathrm{H}_{2} \mathrm{O}$, and partitioned with hexanes $(5.9 \mathrm{~g}$ of a light brown gum). The aqueous $\mathrm{MeOH}$ extract was subsequently evaporated, and the gummy material was solubilized in $\mathrm{CH}_{2} \mathrm{Cl}_{2}-$ $0.5 \mathrm{~N} \mathrm{HCl}$. The $\mathrm{CH}_{2} \mathrm{Cl}_{2}$ fraction was collected and named $\mathrm{CH}_{2} \mathrm{Cl}_{2}$-acid (5.03 g of a light greenish gum). $\mathrm{NaOH}$ (1 N) was added to the aqueous fraction, which was partitioned with $\mathrm{CH}_{2-}$ $\mathrm{Cl}_{2}$. The fraction was named $\mathrm{CH}_{2} \mathrm{Cl}_{2}$-basic $(0.87 \mathrm{~g}$ of a yellow gum). All extracts were analyzed by TLC and revealed the presence of alkaloids (Dragendorff).

The $\mathrm{CH}_{2} \mathrm{Cl}_{2}$-basic extract was fractionated by chromatography on a cyanopropyl-bonded Sep Pak column (10 g) with a gradient of $\mathrm{MeOH}$ in $\mathrm{CH}_{2} \mathrm{Cl}_{2}$ to give two fractions. The first fraction was separated by chromatography on a silica gel Sep Pak column (10 g) with a gradient of $\mathrm{MeOH}$ in $\mathrm{CH}_{2} \mathrm{Cl}_{2}$, to give four fractions. The second fraction was separated by chromatography on a silica gel Sep Pak column $(10 \mathrm{~g})$ with a gradient of $1: 1$ acetonitrile- $\mathrm{MeOH}$ in $\mathrm{CH}_{2} \mathrm{Cl}_{2}$, yielding seven fractions. The fourth one was shown to be pure by ${ }^{1} \mathrm{H}$ and ${ }^{13} \mathrm{C} N M R$, giving $55.7 \mathrm{mg}$ of compound $\mathbf{1}(0.0028 \%$ wet weight).

The $\mathrm{n}-\mathrm{BuOH}$ extract was fractionated by chromatography on an amino-bonded Sep Pak column (10 g) with a gradient of $\mathrm{MeOH}$ in $\mathrm{CH}_{2} \mathrm{Cl}_{2}$. Five fractions were obtained. The second and the fourth fractions were subjected to identical separations by chromatography on Sephadex $\mathrm{LH} 20\left(1: 1 \mathrm{CH}_{2} \mathrm{Cl}_{2}-\mathrm{MeOH}\right)$. The second and third fractions of each of these last separations were shown to be identical by TLC. Therefore, these four 
fractions were all pooled and further separated by chromatography on a cyanopropyl-bonded LOBAR column, with a gradient of $\mathrm{MeOH}$ in $\mathrm{CH}_{2} \mathrm{Cl}_{2}$. The first, fourth, and fifth fractions obtained from this last separation were purified by HPLC (column: $C_{18} \mu$ Bondapak, $7.8 \times 300$ mm, $10 \mu \mathrm{m} 125 \AA_{\text {; }}$ eluents: 9:1 acetonitrile- $\mathrm{H}_{2} \mathrm{O}$ or 7:3 $\mathrm{MeOH}-\mathrm{H}_{2} \mathrm{O}$ ). The two fractions obtained, AmNL IFN5a (3.0 mg) and AmNL 4a (3.0 $\mathrm{mg}$ ), were further analyzed by HPLC-MS/MS. For the HPLCMS separation, a XTerra RP-18 column $(3.0 \times 150 \mathrm{~mm}, 3.5$ $\mu \mathrm{m}$, Waters) was used. Separation was achieved by applying a 30 min gradient from $20 \%$ acetonitrile/80\% formic acid $(0.1 \%$ in water) to $80 \%$ acetonitrile/ $20 \%$ formic acid ( $0.1 \%$ in water), then isocratic conditions during $15 \mathrm{~min}$. Total analysis time was $45 \mathrm{~min}$ with a flow rate of $0.4 \mathrm{~mL} / \mathrm{min}$ and an oven temperature of $30^{\circ} \mathrm{C}$.

Ingenamine G (1): glassy solid; $[\alpha]^{29} \mathrm{D}-59.2$ (c 0.050 , $\mathrm{MeOH}$ ); UV (MeOH) $\lambda_{\max } 230(\epsilon$ 2500) $283(\epsilon$ 625) nm; IR (film on a Si plate) $v_{\max } 3390(\mathrm{OH}), 2929(\mathrm{CH}), 2858(\mathrm{CH}), 2554$ (Bohlmann), 1660, 1447, $1023 \mathrm{~cm}^{-1}$; ${ }^{1} \mathrm{H} \mathrm{NMR}\left(\mathrm{MeOH}-\mathrm{d}_{4}, 400\right.$ $\mathrm{MHz})$, see Table $1 ;{ }^{13} \mathrm{C} \mathrm{NMR}\left(\mathrm{MeOH}-\mathrm{d}_{4}, 100 \mathrm{MHz}\right)$, see Table 1; positive HRFABMS m/z 479.40007 [M $+\mathrm{H}]^{+}$(calcd for $\mathrm{C}_{32} \mathrm{H}_{52} \mathrm{~N}_{2} \mathrm{O} 479.40014$ ).

Cyclostellettamine G (10): UV (HPLC-DAD) $\lambda_{\max } 267 \mathrm{~nm}$; positive ESI-MS m/z 239.2126 M ${ }^{2+}$ (calcd for $\mathrm{C}_{33} \mathrm{H}_{54} \mathrm{~N}_{2} 239.2138$ ), $\Delta \mathrm{m}=5.1 \mathrm{ppm}$. Results for the fragmentation: (a) $\mathrm{m} / \mathrm{z} 232.2052$ $\left[\mathrm{M}-\mathrm{C}_{17} \mathrm{H}_{28} \mathrm{~N}\right]^{+}$(calcd for $\mathrm{C}_{16} \mathrm{H}_{26} \mathrm{~N}$ 232.2060), $\Delta \mathrm{m}=3.2$; (b) $\mathrm{m} / \mathrm{z} 246.2202\left[\mathrm{M}-\mathrm{C}_{16} \mathrm{H}_{26} \mathrm{~N}\right]^{+}$(cal cd for $\mathrm{C}_{17} \mathrm{H}_{28} \mathrm{~N}$ 246.2216) $\Delta \mathrm{m}$ $=5.9$.

Cyclostellettamine H (11): UV (HPLC-DAD) $\lambda_{\max } 267 \mathrm{~nm}$; positive ESI-MS m/z 232.2051 M ${ }^{2+}$ (calcd for $\mathrm{C}_{32} \mathrm{H}_{52} \mathrm{~N}_{2} 232.2060$ ), $\Delta \mathrm{m}=3.6 \mathrm{ppm}$. Results for the fragmentation: (a) $\mathrm{m} / \mathrm{z} 218.1905$ $\left[\mathrm{M}-\mathrm{C}_{17} \mathrm{H}_{28} \mathrm{~N}\right]^{+}$(calcd for $\mathrm{C}_{15} \mathrm{H}_{24} \mathrm{~N} 218.1903$ ), $\Delta \mathrm{m}=0.7$; (b) $\mathrm{m} / \mathrm{z} 246.2216\left[\mathrm{M}-\mathrm{C}_{15} \mathrm{H}_{24} \mathrm{~N}\right]^{+}$(calcd for $\mathrm{C}_{17} \mathrm{H}_{28} \mathrm{~N}$ 246.2216), $\Delta \mathrm{m}=6.7$.

Cyclostellettamine I (12): UV (HPLC-DAD) $\lambda_{\max } 267 \mathrm{~nm}$; positive ESI-MS m/z 239.2127 M ${ }^{2+}$ (calcd for $\mathrm{C}_{33} \mathrm{H}_{54} \mathrm{~N}_{2} 239.2138$ ), $\Delta \mathrm{m}=4.5 \mathrm{ppm}$. Results for the fragmentation: (a) $\mathrm{m} / \mathrm{z} 218.1909$ $\left[\mathrm{M}-\mathrm{C}_{18} \mathrm{H}_{30} \mathrm{~N}\right]^{+}$(calcd for $\mathrm{C}_{15} \mathrm{H}_{24} \mathrm{~N}$ 218.1903), $\Delta \mathrm{m}=2.7$; (b) $\mathrm{m} / \mathrm{z} 260.2349\left[\mathrm{M}-\mathrm{C}_{15} \mathrm{H}_{24} \mathrm{~N}\right]^{+}$(cal cd for $\mathrm{C}_{18} \mathrm{H}_{30} \mathrm{~N}$ 260.2373) $\Delta \mathrm{m}$ $=9.0$.

Cyclostellettamine K (13): UV (HPLC-DAD) $\lambda_{\max } 267 \mathrm{~nm}$; positive ESI-MS m/z 246.2198 M ${ }^{2+}$ (calcd for $\mathrm{C}_{34} \mathrm{H}_{56} \mathrm{~N}_{2} 246.2216$ ), $\Delta \mathrm{m}=7.2 \mathrm{ppm}$. Results for the fragmentation: (a) $\mathrm{m} / \mathrm{z} 218.1907$ $\left[\mathrm{M}-\mathrm{C}_{19} \mathrm{H}_{32} \mathrm{~N}\right]^{+}$(calcd for $\mathrm{C}_{15} \mathrm{H}_{24} \mathrm{~N}$ 218.1903), $\Delta \mathrm{m}=1.5$; (b) $\mathrm{m} / \mathrm{z} 274.2499\left[\mathrm{M}-\mathrm{C}_{15} \mathrm{H}_{24} \mathrm{~N}\right]^{+}$(calcd for $\left.\mathrm{C}_{19} \mathrm{H}_{32} \mathrm{~N} 274.2529\right) \Delta \mathrm{m}$ $=11.2$.

Cyclostellettamine L (14): UV (HPLC-DAD) $\lambda_{\max } 267 \mathrm{~nm}$; positive ESI-MS m/z $253.2271 \mathrm{M}^{2+}$ (calcd. for $\mathrm{C}_{35} \mathrm{H}_{58} \mathrm{~N}_{2}$ 253.2295), $\Delta m=9.3 \mathrm{ppm}$. Results for the fragmentation: (a) $\mathrm{m} / \mathrm{z} 232.2057\left[\mathrm{M}-\mathrm{C}_{19} \mathrm{H}_{32} \mathrm{~N}\right]^{+}$(calcd for $\mathrm{C}_{16} \mathrm{H}_{26} \mathrm{~N}$ 232.2060), $\Delta \mathrm{m}=1.0$; (b) $\mathrm{m} / \mathrm{z} 274.2507\left[\mathrm{M}-\mathrm{C}_{16} \mathrm{H}_{26} \mathrm{~N}\right]^{+}$(calcd for $\mathrm{C}_{19} \mathrm{H}_{32} \mathrm{~N}$ 274.2529) $\Delta \mathrm{m}=8.0$.

Acknowledgment. The authors are indebted to Prof. B. Copp (Department of Chemistry, University of Auckland, Auckland, New Zealand) for his assistance in measuring MS data of compound 1, as well as to Prof. C. Pessoa and M. O. Moraes (Universidade Federal do Ceará) for the cytotoxicity assays, A. O. de Souza (F aculdade de Medicina de Ribeirão Preto, Universidade de São Paulo) for the antituberculosis bioassay, and Prof. G. G. F. Nascimento (Universidade Metodista de Piracicaba) for the antimicrobial bioassays. The logistic and technical support of the Centro de Biologia Marinha of the Universidade de São Paulo is also greatly appreciated. Financial support was provided to R.G.S.B. by grants from FAPESP (01/03095-5) and from NIH (CA 67786). J.H.H.L.O. also thank FAPESP for a scholarship. The authors also thank two anonymous reviewers for many suggestions to improve the manuscript.

Supporting Information Available: This material is available free of charge via the Internet at http://pubs.acs.org.

\section{References and Notes}

(1) Schmitz, F.J .; Hollenbeak, K. H.; Campbell, D. C. J . Org. Chem. 1978, 43, 3916-3922.

(2) Andersen, R. J .; Van Soest, R. W. M.; Kong, F. In Alkal oids: Chemical and Biological Perspectives; Pelletier, S. W., Ed.; Pergamon Press: New York, 1996; Vol. 10, pp 301-355.

(3) Almeida, A. M. P.; Berlinck, R. G. S.; Hajdu, E. Quím. Nova 1997, 20, 170-185.

(4) Sepcic, K.J. Toxicol. Toxin Rev. 2000, 19, 139-160.

(5) Rodriguez, J. Stud. Nat. Prod. Chem. 2000, 24, 573-581.

(6) Peng, J . N.; Hu, J . F.; Kazi, A. B.; Li, Z.; Avery, M.; Peraud, O.; Hill R. T.; Franzblau, S. G.; Zhang, F. Q.; Schinazi, R. F.; Wirtz, S. S. Tharnish, P.; Kelly, M.; Wahyuono, S.; Hamann, M. T.J . Am. Chem Soc. 2003, 125, 13382-13386

(7) Torres, Y. R.; Berlinck, R. G. S.; Magalhães, A.; Schefer, A. B.; Ferreira, A. G.; Hajdu, E.; Muricy, G. J . Nat. Prod. 2000, 63, 10981105.

(8) Torres, Y. R.; Berlinck, R. G. S.; Nascimento, G. G. F.; Fortier, S. C.; Pessoa, C.; Moraes, M. O. Toxicon 2002, 40, 885-891.

(9) (a) Ang, K. K. H.; Holmes, M. J .; Kara, U. A. K. Parasitol. Res. 2001 87, 715-721. (b) Ang, K. K. H.; Holmes, M. J .; Higa, T.; Hamann, M. T.; Kara, U. A. K. Antimicrob. Agents Chemother. 2000, 44, 16451649.

(10) Gafni, J .; Munsch, J . A.; Lam, T. H.; Catlin, M. C.; Costa, L. G.; Molinski, T. F.; Pessah, I. N. Neuron 1997, 19, 723-733.

(11) Berlinck, R. G. S.; Hajdu, E.; Rocha, R. M.; Oliveira, J. H. H. L.; Hernández, I. L. C.; Seleghim, M. H. R.; Granato, A. C.; Almeida, E. V. R.; Nuñez, C. V.; Muricy, G.; Peixinho, S.; Pessoa, C. O.; Moraes, M. O.; Cavalcanti, B. C.; Nascimento, G. G. F.; Thiemann, O., Silva, M. Souza, A. O.: Minarini, P. R. R. J N at. Prod 2004, 67, 510-522

(12) (a) Kong, F.; Andersen, R. J .; Allen, T. M. Tetrahedron Lett. 1994 35, 1643-1646. (b) Kong, F.; Andersen, R. J .; Allen, T. M. Tetrahedron 1994, 50,6137-6144. ${ }^{1} \mathrm{H}$ and ${ }^{13} \mathrm{C}$ chemical shifts of keramaphidin $\mathrm{C}$ have been reassigned. See: (c) Kong, F.; Andersen, R. J . Tetrahedron 1995, 51, 2895-2906.

(13) Kobayashi, J .; Tsuda, M.; Kawasaki, N.; Matsumoto, K.; Adachi, T. Tetrahedron Lett. 1994, 35, 4383-4386.

(14) Rodriguez, J .; Peters, B. M.; Kurz, L.; Schatzman, R. C.; McCarley D. Lou, L. Crews, P I. Am Chem. Soc 1993, 115, 10436-10437.

(15) Volk, C. A.; Köck, M. Org. Lett. 2003, 5, 2567-3569.

(16) Fusetani, N.; Asai, N.; Matsunaga, S.; Honda, K.; Yasumuro, K. Tetrahedron Lett. 1994, 35, 3967-3970.

(17) We have initially named $\mathbf{1 1}$ as cyclostellettamine $\mathrm{G}$ and $\mathbf{1 0}$ as cyclostellettamine $\mathrm{H}$, since $\mathbf{1 1}$ has a smaller number of methylene groups than 10. However, during the preparation of the manuscript we became aware of the recent isolation of cyclostellettamine G (10) by Prof. Fusetani's group, and therefore we have switched the names of both $\mathbf{1 0}$ and 11. Oku, N.; Nagai, K.; Shindoh, N.; Terada, Y.; van Soest, R. W. M.; Matsunaga, S.; F usetani, N. Bioorg. Med. Chem. Lett. 2004, 14, 2617-2620.

(18) Sepcic, K.; Guella, G.; Mancini, I., Pietra, F.; Della Serra, M.; Menestrina, G.; Macek, P.; Tubbs, K.; Turk, T. j. Nat. Prod. 1997, 60, 991-996.

(19) (a) Cimino, G.; de Rosa, S.; de Stefano, S.; Sodano, G. Pure Appl Chem. 1986, 58, 375-386. (b) Cimino, G.; de Stefano, S.; Scognamiglio, G.; Sodano, G. Bull. Soc. Chim. Belg. 1986, 95, 783-800. (c) Cimino, G.; Spinella, S.; Trivellone, E. Tetraderon Lett. 1989, 30, 133-136. (d) Cimino, G.; Puliti, R.; Scognamiglio, G.; Spinella, A.; Trivellone, E. Pure Appl. Chem. 1989, 61, 535-538. (e) Cimino, G.; Mattia, C. A.; Mazzarella, L.; Puliti, R.; Scognamiglio, G.; Trivellone, E. Tetrahedron 1989, 45, 3863-3872. (f) Cimino, G.; Scognamiglio, G. Spinella, A. J. Nat. Prod. 1990, 53, 1519-1525. (g) Cimino, G. Fontana, A.; Madaio, A.; Scognamiglio, G.; Trivellone, E. Magn. Reson. Chem. 1991, 29, 327-332. (h) Guo, Y. W.; Madaio, A.; Trivellone, E. Scognamiglio, G.: Cimino, G. Tetrahedron 1996, 52, 8341-8348. (i) Guo, Y. W.; Trivellone, E.; Scognamiglio, G.; Cimino, G. Tetrahedron Lett. 1998, 39, 463-466.

(20) Baldwin, J. E.; Whitehead, R. C. Tetrahedron Lett. 1992, 33, 2059 2062.

(21) Patil, A. D.; Freyer, A.J .; Taylor, P. B.; Carté, B.; Zuber, G.; J ohnson, R. K.; Faulkner, D. J . J . Org. Chem. 1997, 62, 1814-1819.

NP0498713 